\title{
IN MEMORIAM : WASHINGTON MATTHEWS
}

Washington Matthews, soldier, surgeon, anthropologist, poet, was born in Killiney, county Dublin, Ireland, July 17,1843 , and died in Washington, D. C., April 29, 1905, in his sixty-second year.

Killiney, the little village in which $\mathrm{Dr}$ Matthews first saw the light, is one of the prettiest suburbs of Dublin, a few miles south from the city, with the blue waters of the bay in front and the blue mountains of Wicklow behind. It is locally noted for its ancient ruined church, dating back to the sixth century, and for its gray stoned cromlech, the "Druids' Judgment Seat," linking the present to the dim prehistoric past. In a letter written shortly before the end, he says of the old home place: "In Ireland, residences with grounds around them usually have proper names, a custom which, in America, prevails more in the south than in the north. The house I was born in, still standing ten years ago, was named Glenalua (Gleann-a-luaighe), or 'Valley of Lead.' There was a lead mine near there in the ancient days. It was exhausted years ago, but they still occasionally find small fragments of lead ore when quarrying around Killiney."

Dr Nicholas Blayney Matthews, father of the subject of our notice, was himself a leading physician and university graduate in medicine. With that admiration for free government which makes every Irishman half an American, he named the boy Washington. While the child was still in infancy, the mother, formerly Miss Anna Burke, died, and the father, finding the old walks lonely without the companion of his love, closed up his affairs at home and came to America in 1847 , bringing his two motherless boys with him. After a short residence in Wisconsin, then a territory, he returned with his children to Ireland, where they remained about three years before coming out again to this country, this time to settle in Dubuque, Iowa. Here the boy grew up, having his first education in the common schools, and at seventeen began the study of medicine under his father, with a course of lectures at the medical department of the University of Iowa, from which he 

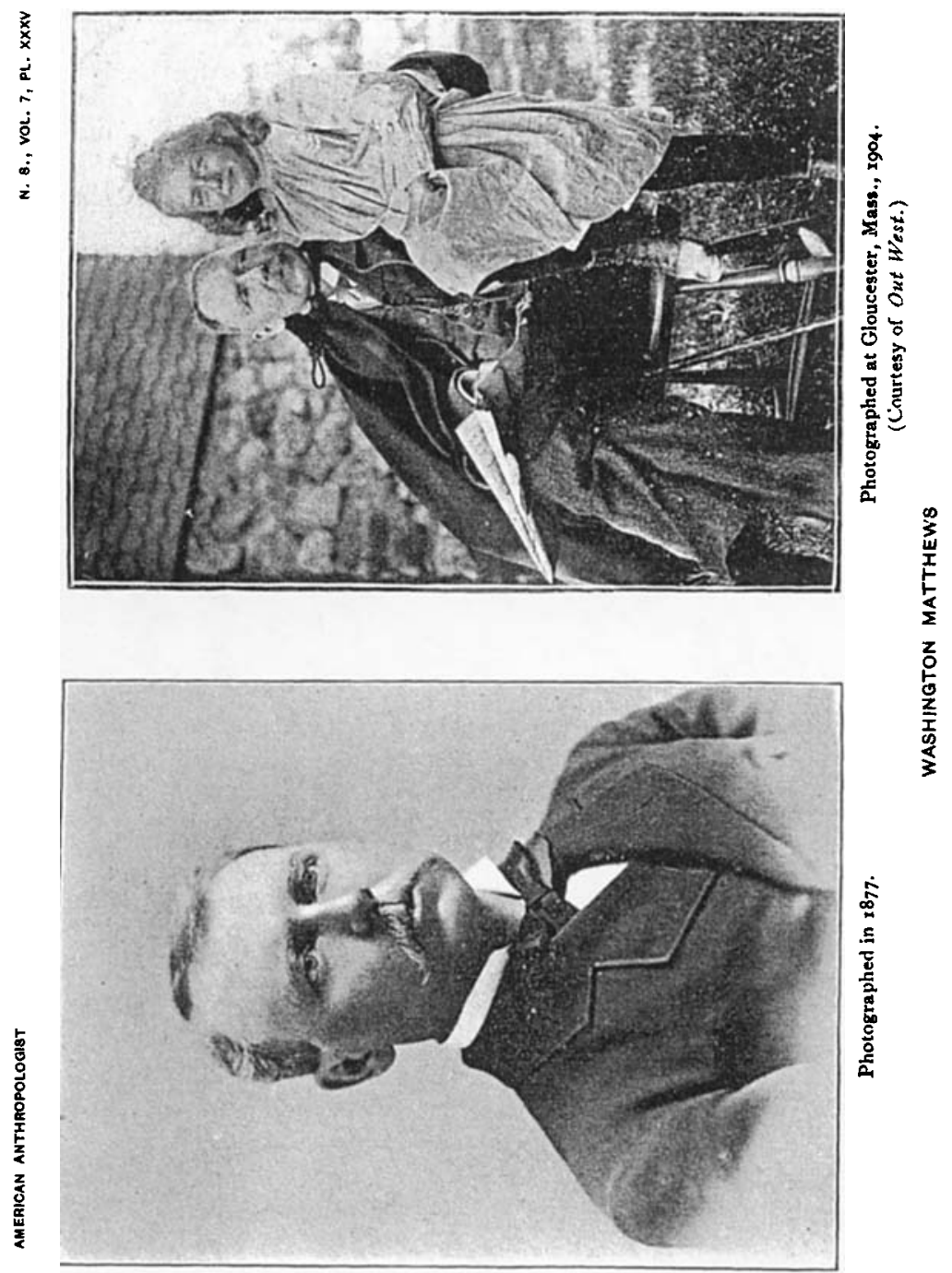

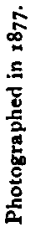



received the degree of M.D., May 28, I 864, in his twenty-first year.

The civil war being then in progress, Dr Matthews at once volunteered for service, and was assigned to duty as acting assistant surgeon at Rock Island, Illinois, looking after the Confederate prisoners in the government hospital at that place. He remained here until mustered out at the close of the war in May, 1865, when he was immediately appointed to the regular army and received an assignment as post surgeon at Fort Union, Montana. Here he first came in close contact with Indians, whom thenceforth he made a life study, at a time when they were still wild and unsubdued.

His subsequent assignments, as given in the army records, are as follow : Post surgeon, Fort Berthold, N. D., I865-66; in the field with General Terry's expedition, Dakota, I867 ; at Fort Stevenson, N. D., 1867-68; post surgeon, Fort Rice, N. D., I86970 ; post surgeon, Fort Buford, N. D., I870-72; post surgeon, David's Island, New York harbor, November to December, 1872 ; post surgeon, Willet's Point, New York harbor, December, 1872 to May, I873; post surgeon, Fort Wood, New York harbor, to June, 1873 ; post surgeon, Fort Sullivan, Maine, to November, 1873 ; post surgeon, David's Island, New York harbor, to November, 1874 ; at Fort Hamilton and Fort Wood, New York harbor, April, 1875; ordered to Department of California, April 23, I875; Alcatraz island, San Francisco harbor, Cal., June, I 875 to April, 1876; post surgeon, Camp Independence, Cal., to July IO, I 877 ; in the field with expedition against Nez Percé Indians, July to October, 1877 ; in the field with expedition against Bannock Indians, 1878 ; at Camp Bidwell, Cal., to June 30 , I 880 ; ordered to the Department of the Missouri, September 7, 1880 ; post surgeon, Fort Wingate, N. Mex., October, 1880 to April, I 884 ; Army Medical Museum, Washington City, $1884-90$; Fort Wingate, N. Mex. (second assignment), I890-94; retired for disability contracted in line of duty, September 29, 1895 . He was commissioned as assistant surgeon in 1868 ; as captain and assistant surgeon in $\mathrm{I} 87 \mathrm{I}$; and as major and surgeon in 1889.

On his first assignment to duty on the upper Missouri in 1865 , Dr Matthews at once became deeply interested in the native tribes 
of that region and soon began the study of the allied Hidatsa (Minitari), Arikara, and Mandan, in the vicinity of Fort Berthold, with whom he remained in close touch for much of the next six years. He brought to this study all the sympathetic enthusiasm of a young man and the exact method of a trained scholar with such good result that he mastered the Hidatsa language - we use the word mastered with its full significance - so that, when under the disheartening misfortune of the entire destruction of all his manuscript notes and his library by the burning of his quarters at Fort Buford in $187 \mathrm{I}$, he was able to rewrite from his inner knowledge the "Grammar and Dictionary of the Hidatsa" and the "Hidatsa (Minnetaree) English Dictionary," which remain to-day the monument and authority on this language. A second and amplified revision of these works was issued by the U. S. Geological and Geographical Survey in 1877 under the title "Ethnography and Philology of the Hidatsa Indians." It was characterized at the time by a competent authority as the most important memoir on our aboriginal languages that had appeared since the great Dakota dictionary of Riggs, twenty-six years before.

In 1877 Dr Matthews married Miss Caroline Wotherspoon, daughter of Dr A. S. Wotherspoon, U. S. Army. In the years thenceforward, whether on the remote frontier or in eastern cities, she was ever his closest companion, his most helpful and interested assistant, his best inspiration, and his tender nurse at the end.

In 1880 , at the suggestion of Major J. W. Powell, director of the Bureau of American Ethnology, he was transferred to duty at Fort Wingate, N. Mex., in the Navaho country, where he remained four years, with a second assignment of four years more in 1890-94. Here, a thousand miles removed from the distractions of civilization, all his spare time and energy, apart from his duties as post surgeon, were given to the study of the great Navaho tribe, at that period uncontaminated heathens, as he himself has happily expressed it. The greater part of this work, of which the first fruits were given to the Bureau of American Ethnology, was entirely a labor of love, at his own personal expense, involving the hiring and usually the feeding of Indian informants and interpreters, with frequent horseback journeys over a difficult country to witness ceremonies, 
identify sites, or collect plants. The results were a marvelous revelation. His "Mountain Chant" and "Prayer of a Navaho Shaman " awakened the scientific world to the possibilities of Indian myth and ritual, and created an interest in the subject which has never slackened. His technologic studies in the same field, as embodied in his papers on Navaho weaving and silverwork, and his botanic and medical studies, chiefly still in manuscript, are of equal importance and alike bear the stamp of careful exactness. The promise held out by his earlier papers has been amply fulfilled by his later and larger works, "Navaho Legends," published as a memoir of the American Folk-Lore Society in 1897, and "The Night Chant," published as a memoir of the American Museum of Natural History in I902.

Of his Navaho studies it has been well written: "The characteristics of his work as an ethnologist are patience, thoroughness, and safety. He does not imagine, but stops with what he knows, and it is safe to be said that his work will stand practically final for the specialty he undertook. Detail students may yet add to our specific knowledge, for his pet tribe will last a long time, but the last generic authority on the Navaho will be, as it is now, Washington Matthews."

For a term of about six years, I884-1890, he was on duty at the Army Medical Museum in Washington, during which period he gave special attention to the study of craniology and anthropometry, subjects at that time hardly considered by American science. Within the same period also he made two important investigating expeditions to the Southwest. The first of these was undertaken in the fall of 1884 , under the auspices of the Bureau of American Ethnology, to the Navaho country, where by previous arrangement with the priests he was privileged to witness the whole secret rite of the Night Chant. The other, in 1887 , was in connection with archeologic investigations in the Salt river valley of Arizona, under the auspices of the Hemenway Southwestern Archeological Expedition. His medical and anatomic writings, chiefly during this time, include a study of consumption among Indians, several notable papers on methods of cranial measurement, and a monograph on "Human Bones of the Hemenway 
Collection," published as a memoir of the National Academy of Sciences in 1893 . In the summer of 1886 he took an opportunity to revisit the places of his childhood in the old land across the sea. In the summer of 1888 he was one of the three physicians selected to attend General Sheridan, lieutenant general of the army, in his last illness. His associates were Dr Robert O'Reilly, now surgeon general, and Dr H. C. Yarrow, both of Washington.

In 1892 , while serving his second assignment at Fort Wingate, he was stricken by the insidious disease which eventually caused his death. Two years later, when it was evident that his day of active service was past, he was recalled to Washington. On September 29,1895 , in accordance with the verdict of an examining board, he was retired for disability.

The disease slowly progressed, but although for several years before the end came he was an almost total physical wreck, unable to go about alone, cut off from conversation, frequently suffering intense agony, and with no hope of recovery, yet he kept his mind clear and his heart brave and warm to the last, and some of his best and most monumental work was produced during weeks of pain when he was scarcely able to move without assistance. At last the strength of what was once a magnificent frame was utterly sapped. While writing at his desk he attempted to rise unaided, but the effort was too great. He fell to the floor, sustaining such injury that medical science was powerless to help, and his life passed away a few weeks later. He was buried as a soldier at Arlington where rest his oldtime friends and associates, Sheridan, Mallery, Bourke, Coues, and Powell. He is survived by his wife, by several relatives in Iowa, and by his father's sister in Ireland.

Dr Matthews took an active interest in scientific things and was a member of the American Anthropological Association, American Association for the Advancement of Science, American Climatological Association, Association of American Anatomists, Anthropological Society of Washington, Philosophical Society of Washington, National Geographic Society, American Folk-Lore Society, Chicago Folk-Lore Society, and Torrey Botanical Club. He served as vice-president of the Chicago Folk-Lore Society in 1894, and as president of the American Folk-Lore Society in 1896 . In 
I 888 he received the degree of LL.D. from his own university in recognition of his philologic work. Besides a fluent knowledge of Hidatsa and a good acquaintance with Navaho, he had at command both German and Spanish, while his English was always a model of literary style. He was an expert botanist, a skilful mathematician, and an artist of some ability in oil colors. Those familiar with his Indian ritual interpretations and with his sometimes concealed identity knew him for a poet even without the proof offered by the following little gem written at Gloucester, Mass., a short time before his death :

\section{THE CONTRAST I}

Dark days around the Gloucester moors

Have come again.

With winds that wail and mists that trail

$O$ 'er land and sea ;

But darker days are in my soul,

Sad is my lot,

Despair and pain are with me here Alice is not.

Bright days around the Gloucester moors Are now with me;

Clear is the sky and fair the land And calm the sea.

The days within my soul are bright, And life is dear ;

For, shining like the sun's own light, Alice is here.

Dark days around the Gloucester moors Have come again.

With northeast gales and slanting sails, And drifting rain.

Sad are the echoes in my soul As breakers' moan,

And like the rain my teardrops fall Alice is gone.

Dr Matthews was a prolific writer, and besides the more impor-tant works already mentioned, was the author of a large number of shorter papers, ethnologic, medical, and general, without counting

1 Printed by courtesy of Mr Charles F. Lummis, editor of Out West, Los Angeles, Cal., in which magazine (May, 1905) the verses, together with the accompanying recent portrait of Dr Matthews, first appeared. 
numerous reviews and notes in the journals in which he was most interested. He left a large body of undigested manuscript material, relating chiefly to the Navaho, Modoc, and Paiute, which is now in possession of the University of California.

The world knows and will increasingly appreciate the scholar, but only those who were near to him can understand the rare personality of the man. Physically, mentally, and morally, Washington Matthews was of the highest type of manhood. Of fine physique and soldierly bearing, with a strong and well-modulated voice, carrying perhaps just a little roll to make it all the more musical, he was one to attract the attention of any audience and hold it to the close. His thought was always well ordered, and the expression so gracefully chosen that each word fitted to its purpose as perfectly as the pieces of an Italian mosaic. By a faculty of mingled sympathy and command he won the confidence of the Indian and the knowledge of his secrets, while by virtue of that spiritual vision which was his Keltic inheritance, he was able to look into the soul of primitive things and interpret their meaning as few others have done. He had a deep sense of the physician's mission in the relief of human suffering. With a modesty that shrank from publicity and despised notoriety, he was without jealousy and rejoiced always in the successful reputation of others. One of his last utterances in life was an expression of pleasure at a merited testimonial to a fellow worker. Of sensitive honor and high courage, he was at all times immediate and unsparing in denunciation of anything that savored of cowardice or dishonesty. His humor was keen, without the sting of sarcasm, and so spontaneous that even his serious discourse was often lightened by the play of fancy.

And now, though the golden bowl be broken, not yet shall the silver cord be loosed that held us in affection to one of whom it can be said in full measure -

"His life was gentle, and the elements So mix'd in him that Nature might stand up And say to all the world, "This was a man!'?"

J. M. 


\section{BIBLIOGRAPHY OF WASHINGTON MATTHEWS}

I. Grammar and dictionary of the language of the Hidatsa (Minnetarees, Grosventres of the Missouri). With an introductory sketch of the tribe. (Shea's Am. Linguistics, ser. II, no. 1, N. Y., 1873 ; $x \times v, 158$ p.)

2. Hidatsa (Minnetaree) English dictionary. (Shea's Am. Linguistics, ser. II, no. 2, p. I49-169, N. Y., 1874.)

3. Ethnography and philology of the Hidatsa Indians. (U.S. Geol. and Geog. Surv., Misc. Pub. no. 7, Wash., 1877 ; 239 P., 8०.)

4. The pagan martyrs. [Anonymous poem.] (Accompanies The Tenacity of Indian Customs, by Sylvester Baxter, in Am. Architect, no. 356, Bost., Oct. 21, 1882.)

5. Navajo silversmiths. (Second Ann. Rep. Bur. Ethnol., p. 167-178, pl. I6-20, Wash., I883.)

6. A part of the Navajo mythology. (Am. Antiquarian, vol. v, p. 207224, Chicago, Apr. 1883.)

7. Navajo weavers. (Third Ann. Rep. Bitr. Ethnol., p. 371-391, pl. 2438, Wash., 1884.)

8. A night with the Navajos. By Zay Elini. (Forest and Stream, vol, XXIII, p. $282-283$, N. Y., Nov. 6 , 1884.)

9. Mythological dry-painting of the Navajos. [Abstract.] (Trans. Anthr. Soc. Wash., vol. III, p. 139-140, Wash., 1885.)

Io. The cubature of the skull. [Abstract.] (Ibid., p. 171-172.)

I I. Mythic dry-paintings of the Navajos. (Am. Naturalist, vol. Xix, p. 93I939, Phila., Oct. 1885.)

12. The origin of the Utes. A Navajo myth. (Am. Antiqunrian, vol. vir, p. 27 I-274, Chicago, Sept. 1885.)
13. On composite photography as applied to craniology, by J. S. Billings ; and on measuring the cubic capacity of skulls, by Washington Matthews. Read April 22, I885. (Mem. Nat. Acad. Sci., vol. II, pt. 2, 13th mem., p. 103-116, 19 pl., Wash., 1886.)

14. On a new craniophore for use in making composite photographs of skulls. By John S. Billings and Washington Matthews. Read Nov, I2, 1885 . (Ibid., vol. III, pt. 2, I4th mem., p. I I 7-I I9, 4 pl., Wash., 1886.)

15. Apparatus for tracing orthogonal projections of the skull in the U. S. Army Medical Museum. ( $J$. Anat. and Physiol., vol. XXI, p. 43-45, 1 pl., Edinb., I886.)

16. An apparatus for determining the angle of torsion of the humerus. (Ibid., p. $53^{6-538 .)}$

17. Navajo names for plants. (Am. Naturalist, vol. $\mathrm{xx}$, p. 767-777, Phila., Sept. I 886.)

18. Some deities and demons of the Navajos. (Ibid., p. 84I-850, Oct. I886.)

i I9. The mountain chant: A Navajo ceremony. (Fifth Ann. Rep. Bur. Ethnol., p. 379-467, pl. Io-18, Wash., I887.)

20. The study of consumption among the Indians. $(N . Y$. Med. J., July 30, 1887.)

21. The prayer of a Navajo shaman. (Am. Anthropol., vol. I, P. I49170, Wash., Apr. I888.)

22. A further contribution to the study of consumption among the Indians. (Trans. Am. Climatol. Ass'n. [Washington meeting, Sept. I 8-20, 1888], p. 136-155, Phila., 1888.) 
23. Two Mandan chiefs. (Am. Antiquarian, vol. $\mathrm{x}$, p. 269-272, 2 pl., Chicago, Sept. 1888 .)

24. Navajo gambling songs. ( $A m$. $A n$ thropol., vol. II, p. I-I9, Wash., Jan. 1889.)

25. Noqoilpi, the gambler : a Navajo myth. (J.Am. Folk-Lore, vol. II, p. 89-94, Bost. and N. Y., Apr.June, 1889.)

26. The Inca bone and kindred formations among the ancient Arizonians. ( $\mathrm{Am}$. Anthropol., vol. II, p. 337-345, Wash., Oct. I889.)

27. The gentile system of the Navajo Indians. (J.Am. Folk-Lore, vol. III, p. 89-IIO, Bost. and N. Y., Apr.-June, 1890.)

28. The Catlin collection of Indian paintings. (ReF. U. S. Nat. Mus. 1890 . p. 593-610, pl. 130-140, Wash., I892.)

29. Meaning of the word "Arikara." (Am. Anthropol., vol. v, p. 35-36, Wash., Jan. 1892.)

30. A study in butts and tips. (Ibid., p. 345-350, Oct. 1892.)

31. Human bones of the Hemenway collection in the U. S. Army Medical Museum. (Mem. Nat. Acad. Sci., vol. vi, 7th mem., p. 139-286, 57 pl., Wash., I893.)

32. Navajo dye stuffs. (Smithson. Rep. I89t, p. 613-615, Wash., I893.)

33. The basket drum. (Am. Anthropol., vol. viI, p. 202-208, Wash., Apr. 1894.)

34. Some jllustrations of the connection between myth and ceremony. (Mem. Int. Cong. Anthropol., p. 246-25 I, Chicago, I894.)

35. Songs of sequence of the Navajos. (J.Amt. Folk-Lore, vol. viI, p. 185194, Bost. and N. Y., July-Sept. I894.)
336. Mt. Taylor. (Am. Antiquarian, vol. Xvir, p. 294, Chicago, 1895.)

37. A vigil of the gods - a Navajo ceremony. (Am. Anthropol., vol. IX, p. 50-57, Wash., Feb. 1896.)

38. Songs of the Navajos. (Land of Sunshine, vol. v, p. 197-201, I pl., Los Angeles, Oct. 18g6.)

39. In memoriam : John Gregory Bourke. (Science, N. Y., Dec. 4, 1896.)

40. Navaho legends. (Mem. Am. FolkLore Soc., vol. v, Bost. and N. Y., I897; viii, 299 p., map, 7 pl., 8०.)

41. The study of ceremony. (J. Am. Folk-Lore, vol. X, p. 259-263, Bost. and N. Y., Oct.-Dec. I897.)

42. Ichthyophobia. (Ibid., vol. XI, P. 105-112, Apr.-June, 1898.)

43. Use of rubber bags in gauging cranial capacity. (Am. Anthropol., vol. $\mathrm{xI}$, p. I71-176, Wash., June 1898 .)

44. Serpent worship among the Navajos. (Land of Sunshine, vol. IX, p. 228235, Los Angeles, Oct. I898.)

45. Some sacred objects of the Navajo rites. (Archives Int. Folk-Lore Ass'n, World's Col. Expos., p. 227247, 5 pl., Chicago, I898.)

46. The study of ethics among the lower races. (J. Am. Folk-Lore, vol. XII, P. I-9, Bost. and N. Y., Jan.Mar. 1899.)

47. Seeking the lost Adam [mine]. (Land of Sunshine, vol. $\mathrm{x}, \mathrm{p}$. I13125, Los Angeles, Feb. I899.)

48. The cities of the dead. (Ibid., vol. XI1, p. 213-221, Mar. 189o.)

49. A two-faced Navaho blanket. ( $\mathrm{Am}$. Anthropol, n. s., vol. II, p. 638642, I pl., N. Y., Oct.-Dec. 1900.)

50. Navaho night chant. (J. Am. FolkLore, vol. $\mathrm{xv}$, p. 12-19, 2 pl., Bost. and N. Y., Jan.-Mar. Igor.)

5x. The treatment of ailing gods. (Ibid., p. 20-23.) 
52. A Navaho initiation. (Land of Sunshine, vol. $\mathrm{xv}, 353-356$, Los Angeles, Nov. 1901.)

53. The earth lodge in art. (Am. $A n$ thropol., n. s., vol. IV, D. I-12, IO pl., N. Y., Jan.-Mar. 1902.)

54. Myths of gestation and parturition. (Ibid., p. 737-742, Oct.-Dec. I902.)

55. The night chant, a Navaho ceremony. (Mem. Am. Mus Nat. Hist., An. thropology, vol. v; N. Y., I902, xvi, 332 pp., 8 pl.)
56. Was willow bark smoked by Indians? (Ibid., vol. v, p. I7o, Lancaster, Pa., Jan.-Mar. I903.)

57. The Navaho yellow dye. (Ibid., vol. vI, p. 194, Jan.-Mar. 1904.)

58. The contrast. [In verse.] (Out West, vol. xxil, p. 304-305, Los Angeles, May, 1905.)

59. [Various articles on Indian manners and customs and on the Navaho tribe, in the Handbook of the Indians, in press for the Bureau of American Ethnology.] 